\title{
Extended Release Chewable Tablet
}

National Cancer Institute

\section{Source}

National Cancer Institute. Extended Release Chewable Tablet. NCI Thesaurus. Code C124794.

A tablet that must be chewed in order to release active and/or inert ing redient(s) at a controlled, prolonged rate so as to reduce dosing frequency. 